\title{
Medicinal Plants Used in Meriç Town from Turkey
}

\author{
Çiler Kartal $^{1 *}$, Fatma Güneş ${ }^{2}$ \\ ${ }^{1}$ Trakya University, Faculty of Science, Department of Biology, Edirne, TURKEY \\ ${ }^{2}$ Trakya University, Faculty of Pharmacy, Department of Pharmaceutical Botany, Edirne, TURKEY
}

\begin{abstract}
Background: There are a few studies on medical plants used in the Trakya region of Turkey (Havsa, Lalapasa, Uzunköprü, Ipsala, Enez, Kirklareli). However, there has been no research study performed investigating the preparation and medicinal uses of wild plants in Meric town. Aim: The aim of this study is to determine the parts of locally growing medicinal plants used by local people in Meric town and the purpose of their use. Methods: In this study, 16 villages in Meriç town (Edirne province, Turkey) were visited, and interviews were performed with 38 persons in total. Results: As result of the study, 24 plant taxa in 19 families were recorded as medicinal plants used by local people. Conclusion: These traditional medicinal plants have been mostly used for the treatment of diabetes, stomach ailments, hemorrhoids, rheumatism and asthma.
\end{abstract}

Keywords: Edirne, Ethnobotany, Medicinal plants, Meriç town, Turkey.

\section{INTRODUCTION}

Local people are using plants growing naturally near their homes for many different purposes. Güneş and Özhatay denote that approximately 500 plants are used for medical purposes in Turkey. ${ }^{1}$ Prior ethnobotanical studies implemented in Trakya region have investigated the local names and ethnobotanic properties of wild plants growing in Edirne (Havsa, Lalapaşa, Uzunköprü, İpsala and Enez) and Kurklareli. ${ }^{2-7}$ However, there has been no research study performed investigating the local names, ethnobotanical properties, and preparation and medicinal uses of wild plants in Meriç town. The aim of this study is to determine the parts of locally growing medicinal plants used by local people in Meriç town and the purpose of their use.

\section{MATERIAL AND METHODS}

The study was performed from March to October in the years 2013-2015 in Meriç town (Edirne - Turkey) and the surrounding 16 villages. Data, including local plant names, diseases treated, therapeutic effects, parts of plants used, methods of preparation, methods of administration, doses and duration of treatment, was obtained from 38 local people through individual, face-to-face interviews. The identification of the plant species determined to be used for medicinal purposes was based on Flora of Turkey and East Aegean Islands. ${ }^{8-10}$ The plant samples identified are being kept in the Faculty of Pharmacy of Trakya University.

\section{RESULTS AND DISCUSSION}

As a result of the study, 24 plant taxa in 19 families were recorded as medicinal plants used by local people. The families and scientific names of the plants, their local names, usable parts and forms of utilization were listed alphabetically in Table 1 . These traditional medicinal plants have been mostly used for the treatment of diabetes, stomach ailments, hemorrhoids, rheumatism and asthma. The most frequently used parts of the plants were aerial parts, leaves, fruits, seeds and flowers. Decoction and infusion are the methods most frequently used for the preparation of the remedies, and the
DOI: 10.5530/ijper.51.3s.23 Correspondence:

\section{Çiler Kartal,}

Trakya University, Faculty of Science, Department of Biology, Edirne, TURKEY Phone no: +90 2842352825 E-mail: cilermeric@yahoo. com 


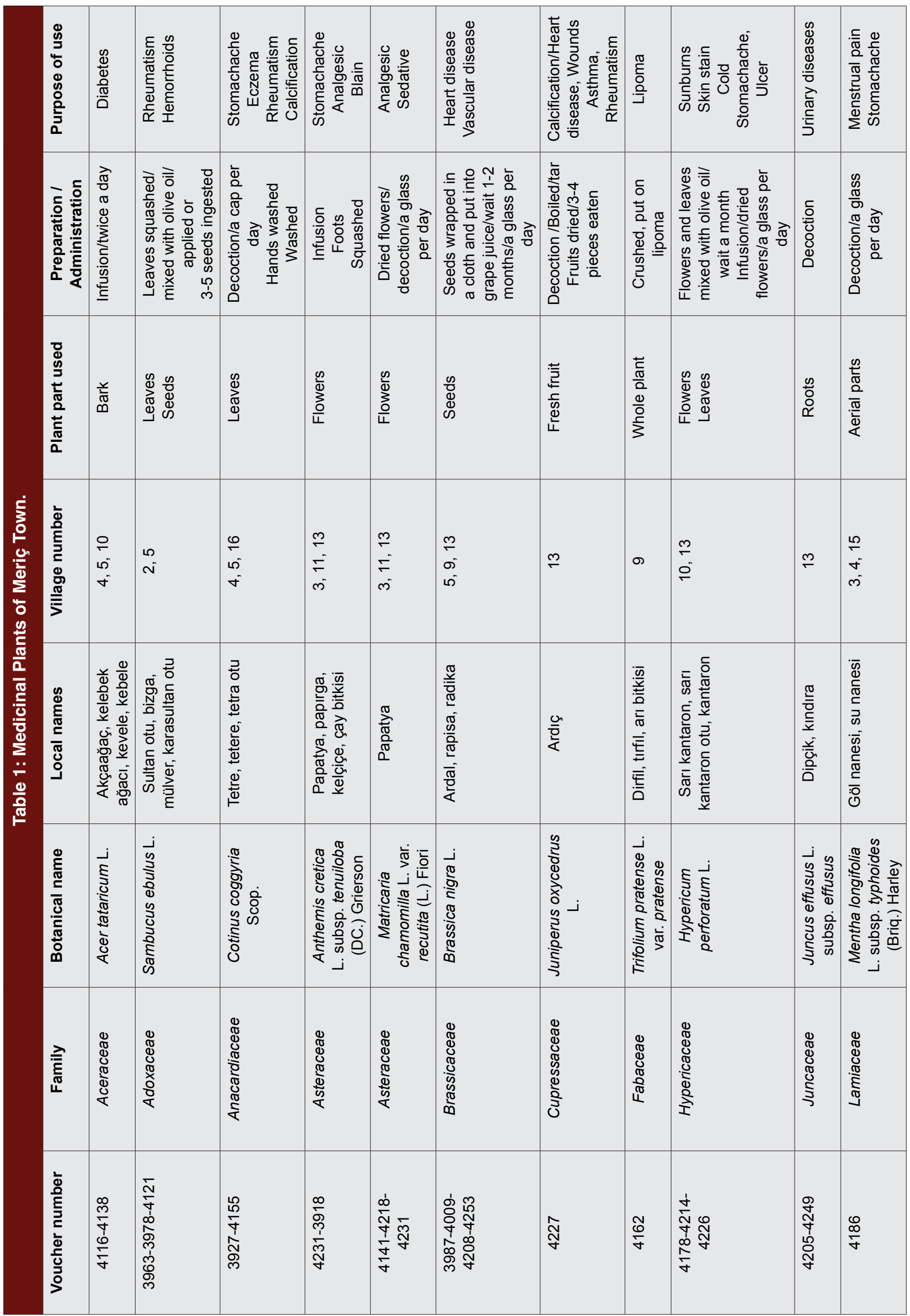




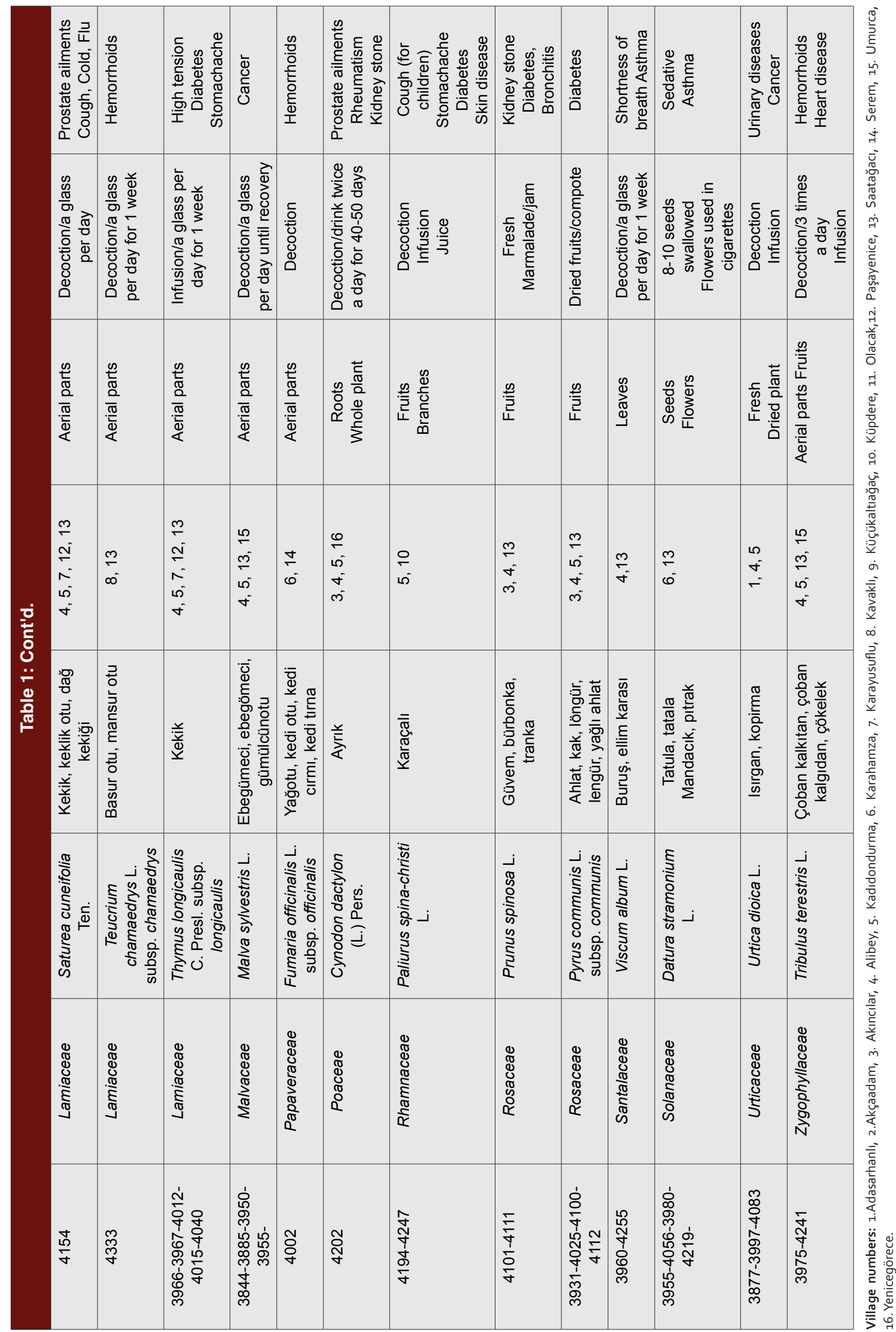


most commonly used plant families were Lamiaceae, Rosaceae and Asteraceae.

This study found that many of the plants had uses similar to plants in this region and the other countries examined in previous ethnobotanical studies. ${ }^{2-7-11-15}$ However, different uses were revealed for Brassica nigra (for heart and vascular diseases), Trifolium pratense var. pratense (for lipoma), and Thymus longicaulis subsp. longicaulis (for high tension and diabetes).

\section{CONCLUSION}

This is the first ethno botanical study about the local names and uses of naturally growing medicinal plants conducted in Meriç town located in Edirne province, Turkey. It is important to document this valuable information because the transfer of knowledge from older generations to newer generations is diminishing.

\section{ACKNOWLEDGEMENTS}

The author would like to thank to all the villagers of Meriç town who collaborated in the realization of this study. This study was supported by The Scientific Research Fund of Trakya University (Project no. TUBAP 2013/22).

\section{CONFLICT OF INTEREST}

None

\section{ABBREVIATION USED}

TUBAP: Trakya University Scientific Research Project.

\section{REFERENCES}

1. Güneş F, Özhatay N. An ethnobotanical study from Kars (Eastern) Turkey. Bio Di Con. 2011;4(1):30-41.

2. Kültür Ş. Medicinal plants used in Kırklareli province (Turkey). J Ethnopharmacol. 2007;111(2):341-64.

3. Tuzlacı E, İşbilen DFA, Bulut G. Turkish folk medicinal plants, VIII: Lalapaşa (Edirne). Marmara Pharm J. 2010;14(1):47-52.

4. Güneş F. Medicinal Plants Used in Merkez and Havsa Towns from Edirne. In: Babaç MT, Aytaç Z, editors. 1. National Plant Biology Congress; 2015 Sep 2-4; Bolu; 2015.

5. Güneş F. Meriç Ç. Medicinal Plants Used in Uzunköprü Town from Turkey. In. Bogdanović S, Jogan N, editors. 6th Balkan Botanical Congress; 2015 Sep 14-18; Rijeka; 2015.

6. Güneş F. Medicinal Plants Used in İpsala Town from Edirne. In: Ünlü A, editor. 3. Symposium on Medicinal and Aromatic Plants; 2016 October 4-6; Antalya; 2016.

7. Kartal Ç. 2016. Medicinal Plants Used in Enez Town from Edirne. In: Ünlü A, editor. 3. Symposium on Medicinal and Aromatic Plants; 2016 October 4-6; Antalya; 2016.

8. Davis PH. Flora of Turkey and the Aegean Islands. Vol. 1-9. Edinburgh University Press, Edinburgh; 1965-1985

9. Davis PH, Miller RR, Tan K. Flora of Turkey and the Aegean Islands. Vol. 10. Edinburgh University Press, Edinburgh; 1988.

10. Güner A, Aslan S, Ekim T, Vural M, Babaç MT, editors. List of Turkey Plants (Vascular Plants): Nezahat Gökyiğit Botanic Garden and Flora Researchers Association Press, Istanbul; 2012.

11. Ebrahimzadeh MA, Ehsanifar S, Eslami B. Sambucus ebulus elburensis fruits: A good source for antioxidants. Phcog Mag. 2009;5(19):213-8

12. Ravindra Babu DS, Neeharika V, Pallavi V, Reddy MB. Antidiarrheal activity of Cynodon dactylon Pers. Phcog Mag. 2009:5(Suppl S2):23-7

13. Vieira A. A comparison of traditional anti-inflammation and anti-infection medicinal plants with current evidence from biomedical research: Results from a regional study. Phcog Res. 2010;2(5):293-5

14. Singh O, Khanam Z, Misra N, Srivastava MK. Chamomile (Matricaria chamomilla L.): An overview. Phcog Rev. 2011;5(9):82-95

15. Shekarchi M, Hajimehdipoor $H$, Saeidnia S, Gohari AR, Hamedani MP. Comparative study of rosmarinic acid content in some plants of Labiatae family. Phcog Mag. 2012;8(29):37-41.

\section{SUMMARY}

- The information was obtained by interviewing 38 local people face to face in Meriç town.

- As a result of the study, 24 plant taxa in 19 families were recorded as medicinal plants used by local people.

- These traditional medicinal plants have been mostly used for the treatment of diabetes, stomach ailments, hemorrhoids, rheumatism and asthma.

- The most frequently used parts of the plants were aerial parts, leaves, fruits, seeds and flowers.

- The different uses were revealed for Brassica nigra (for heart and vascular diseases), Trifolium pratense var. pratense (for lipoma), and Thymus longicaulis subsp. longicaulis (for high tension and diabetes) in Meriç town. 


\section{ABOUT AUTHORS}

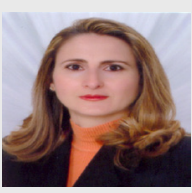

Dr. Çiler Kartal: Working as Botany Professor at the Trakya University, Faculty of Science, Department of Biology, Edirne, Turkey. Her research area includes plant anatomy, plant embryology and ethnobotany.

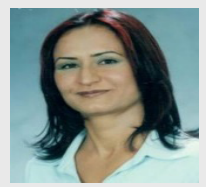

Dr. Fatma Güneș: Working as Assoc. Professor at the Trakya University, Faculty of Pharmacy, Department of Pharmaceutical Botany, Edirne, Turkey. Her research area includes plant morphology and ethnobotany.

Cite this article: Kartal Ç, Günes F. Medicinal Plants Used in Meriç Town from Turkey. Indian J of Pharmaceutical Education and Research. 2017;51(3)Suppl:249-53. 